\title{
Genomic characterization of large rearrangements of the $L D L R$ gene in Czech patients with familial hypercholesterolemia
}

\author{
Radan Goldmann', Lukáš Tichý1, Tomáš Freiberger², Petra Zapletalová1, Ondřej Letocha', Vladimír Soška',
} Jiř́ Fajkus ${ }^{4}$, Lenka Fajkusová ${ }^{14^{*}}$

\begin{abstract}
Background: Mutations in the $L D L R$ gene are the most frequent cause of Familial hypercholesterolemia, an autosomal dominant disease characterised by elevated concentrations of LDL in blood plasma. In many populations, large genomic rearrangements account for approximately $10 \%$ of mutations in the $L D L R$ gene.

Methods: DNA diagnostics of large genomic rearrangements was based on Multiple Ligation dependent Probe Amplification (MLPA). Subsequent analyses of deletion and duplication breakpoints were performed using longrange $P C R, P C R$, and DNA sequencing.

Results: In set of 1441 unrelated FH patients, large genomic rearrangements were found in 37 probands. Eight different types of rearrangements were detected, from them 6 types were novel, not described so far. In all rearrangements, we characterized their exact extent and breakpoint sequences.

Conclusions: Sequence analysis of deletion and duplication breakpoints indicates that intrachromatid non-allelic homologous recombination (NAHR) between Alu elements is involved in 6 events, while a non-homologous end joining (NHEJ) is implicated in 2 rearrangements. Our study thus describes for the first time NHEJ as a mechanism involved in genomic rearrangements in the $L D L R$ gene.
\end{abstract}

\section{Background}

Familial hypercholesterolemia (FH) is an autosomal dominant disease, caused predominantly by variants in the low density lipoprotein receptor $(L D L R)$ gene. Pathogenic alternations in the LDLR protein cause a lack of functional receptors for LDL particles on the liver cell surface and give rise to increased serum LDLcholesterol levels. The high LDL-cholesterol level frequently gives rise to tendon xanthomas, xanthelasmas, arcus lipoides corneae, and accelerated atherosclerosis resulting from cholesterol deposition in the arterial wall, thereby increasing the risk of premature coronary heart disease. The frequency of heterozygous $\mathrm{FH}$ in most populations is about $1 / 500$, homozygous $\mathrm{FH}$ is rare $(\leq$ 1/1000,000) [1]. The identification and treatment of FH

\footnotetext{
* Correspondence: lenkafajkusova@volny.cz

'University Hospital Brno, Centre of Molecular Biology and Gene Therapy,

Černopolní 9, CZ-62500 Brno, Czech Republic

Full list of author information is available at the end of the article
}

patients and their affected relatives with effective lipidlowering agents is important and as this has been shown to significantly reduce both coronary morbidity and mortality $[2,3]$. Genetic testing is the preferred diagnostic method in $\mathrm{FH}$ families because it provides an unequivocal diagnosis $[1,4,5]$. The $L D L R$ gene is localized at 19p13.2, is composed of 18 exons spanning 45 $\mathrm{kb}$, the transcript is $5.3 \mathrm{~kb}$ long and encodes a peptide containing 860 amino acids [6]. LDLR mutations have been reported along the whole length of the gene in $\mathrm{FH}$ patients from around the world. At present, the number of identified unique $L D L R$ allelic variants is over 1000: $65 \%$ of the variants are DNA substitutions, $24 \%$ small DNA rearrangements $(<100 \mathrm{bp})$ and $11 \%$ large DNA rearrangements (> $100 \mathrm{bp}$ ) http://www.ucl.ac.uk/ldlr/ Current/index.php?select_db=LDLR and [7].

Genesis of large DNA rearrangements in the $L D L R$ gene is frequently associated with $A l u$ elements, which are highly abundant in this particular locus $[6,8,9]$. 
Publication of the human genome DNA sequence has revealed that there are $98 \mathrm{Alu}$ repeats within the $L D L R$ gene (95 in intronic sequences and 3 in the 3'untranslated region) and $A l u$ repeats accounted for $65 \%$ of $L D L R$ intronic sequences [10].

$A l u$ is the most abundant short interspersed nuclear element (SINE) of the human genome, occupying 10\% of the genome content with a copy number estimated to be at least 1.3 million [11]. Consensus Alu sequence is approximately $300 \mathrm{bp}$ in length, and consists of two similar, but distinct monomers. The longer right $A l u$ monomer contains a $31 \mathrm{bp}$ insert absent from the left Alu monomer. A functional RNA polymerase III promoter is present in the left monomer, but is absent from the right monomer [12,13]. Alu sequences are regarded as retrotransposons that have inserted into the human genome via a single-stranded RNA intermediate generated by RNA pol III transcription [14]. The Alu dimer is usually followed by a 3'A-rich region, a typical feature of SINEs, and the two monomers are separated by a middle A-rich region, an obvious remnant of an ancestral monomeric Alu's 3'A-rich tail [15].

Throughout Alu evolution, the source gene(s) accumulated mutations that were incorporated into the new copies made, creating new Alu subfamilies. Therefore, the Alu family is composed of a number of distinct subfamilies characterized by a hierarchical series of mutations that result in a series of subfamilies of different ages [16-20].

Alu repeat dispersion throughout the genome offers many opportunities for homologous recombinations. Nonallelic homologous recombination (NAHR) is the most common mechanism underlying disease associated genome rearrangements. NAHR can use either regionspecific low-copy repeats or repetitive sequences (e.g., $A l u)$ as homologous recombination substrates $[21,22]$. Another recombination mechanism causing genomic disorders is nonhomologous end joining (NHEJ). This process involves the double strand breakage of DNA followed by end joining in the absence of extensive sequence homology [23-25]. NHEJ is associated with very short stretches of sequence identity (a few bp) between the two ends of the breakpoint junctions $[22,26,27]$.

In this study, we present results of analyses of large genomic rearrangements in Czech $\mathrm{FH}$ patients detected using Multiple Ligation dependent Probe Amplification (MLPA). In set of 1441 unrelated FH patients, large genomic rearrangements were detected in 37 probands. We found 8 different types of rearrangements, from them 6 types were novel, not described so far. In all rearrangements, we characterized their exact extent and breakpoint sequences. The results showed that 6 events were products of NAHR between $A l u$ repeat sequences.
The remaining 2 events apparently originated from NHEJ.

\section{Methods \\ Patients}

One thousand nine hundred and forty five probands with probable or definite diagnosis of $\mathrm{FH}$, submitted to the database of the MedPed (Make Early Diagnoses to Prevent Early Deaths) project in the Czech Republic, were included into the study. MedPed is an international project joining together experts from more than 30 countries of the world. In the Czech Republic, the project is coordinated by the Czech Society for Atherosclerosis. Experimental research reported in this study has been performed with the approval of the Ethical Committee of the General University Hospital in Prague, the Czech Republic, and is in compliance with the Helsinki Declaration. All patients gave their informed consent with their participation in the study, which is a part of each patient's personal documentation. The text of the informed consent is available at: http://www.athero. cz/user_data/zpravodajstvi/obrazky/File/medped/informovany_souhlas.pdf The patient file in our study include a) patients with untreated total and/or LDL cholesterol serum levels above the $95^{\text {th }}$ percentile of age, sex and population specific values; b) patients with elevated total and LDL cholesterol in serum but untreated levels unavailable or not exceeding the $95^{\text {th }}$ percentile of age, sex and population specific values, and, in addition, with high clinical suspicion of FH based on personal history and/or family history of premature coronary heart disease and/or elevated total and LDL cholesterol serum levels in the first degree relatives.

DNA analysis of FH patients is divided into several consecutive steps: 1) PCR-RFLP detection of the most common mutation in the $A P O B$ gene (p.Arg3527Gln) [28,29]; 2) PCR-RFLP detection of the most common mutations in the LDLR gene (p.Gly592Glu, p. Asp266Glu, and p.Arg416Trp); 3) PCR-sequencing of $L D L R$ exon 4 (the exon with the greatest occurrence of mutations in Czech FH patients); 4) MLPA analysis of all $L D L R$ exons; 5) PCR-sequencing of the promoter and $L D L R$ exons $1,5,6,9,10,12,14$; and 6) PCR-denaturing high performance liquid chromatography of $L D L R$ exons $2,3,7,8,11,13,15,16,17$, and 18 , followed by sequencing of positively tested regions.

The break of DNA analysis in case of a mutation finding depends on personal and family history of hypercholesterolemia, the presence of tendon xanthomas, xanthelasmas, early coronary artery disease and premature coronary heart disease. The DNA analysis continues in cases when i) a phenotype manifestation could be associated with the presence of two LDLR mutations or ii) a detected missense mutation is new with hardly 
predicted effect on the protein structure and function. This diagnostic process is common in $\mathrm{FH}$ diagnostics [30,31]. Only data obtained by MLPA analysis are present in this study.

\section{Analysis of deletion and duplication breakpoints in the LDLR gene}

DNA was isolated according to the standard salting-out method. MLPA was performed using SALSA MLPA KIT P062-C1 LDLR (MRC-Holland), according to the manufacturer's instruction, and analysed on CEQ 8000 Genetic Analysis System (Beckman Coulter). To characterize the precise locations of genomic breakpoints, a number of amplifications and PCR product analyses were performed. Primers for initial long-range amplifications are given in Table 1 together with approximate sizes of PCR fragments of mutated alleles and nested primers for precise determination breakpoints using DNA sequencing. Long-range PCR were performed using Expand Long Template PCR System Kit (Roche) and PCR amplifying fragments around breakpoints using AmpliTaq Gold polymerase (Applied Biosystems). PCR products were purified and sequenced on ABI PRISM 310 DNA-sequencer (Applied Biosystems). Repetitive sequences were identified using RepeatMasker version3.1.5 available at http://www.repeatmasker.org/cgi-bin/ WEBRepeatMasker.

\section{Results}

For DNA analysis, 1945 FH probands were selected: 252 probands $(13,0 \%)$ had the $A P O B$ mutation; 186 probands $(9,6 \%)$ had the mutation p.Gly592Glu or p. Asp266Glu or p.Arg416Trp; 66 probands (3,4\%) had a mutation in exon 4. 1441 patients were analyzed by MLPA and in 37 probands $(1,9 \%)$ a deletion/duplication was detected. At present time, the DNA analysis continues in 1404 patients.

Using MLPA, we found 8 types of large genomic rearrangements - 5 deletions and 3 duplications (Table 2). Six types of rearrangements were novel, so far not described: exon2_6dup, exon3_12del, exon4_8dup, exon5_10del, exon9_15del, and exon16_18dup (The terminology used should be read e.g., in exon2_6dup as duplication of exon 2 to exon 6). Using long-range PCR, PCR, and DNA sequencing, we analysed breakpoints of deletions and duplications identified in our $\mathrm{FH}$ patients. In Table 2, we show correct sizes of deletions and duplications together with terms of repetitive elements surrounding breakpoints. Schematic illustration of recombination events are given in Figure 1 and 2. As new rearrangements, we denote deletions/duplications which have not been described in literature so far in terms of exons involved. In this denotation, we do not take into account the exact sequence position of breakpoints determined in this work.

NAHR was detected in six DNA rearrangements (promoter_exon2del, exon2_6dup, exon3_12del, exon9_14del, and exon9_15del, exon16_18dup). In four NĀHRs (promoter_exon2del, exon2_6dup, exon9_14del, and exon16_18dup), extensive sequence identity was detected between the breakpoints. In all four cases, the rearrangements were caused by recombination between consensus $A l u$ repeats and novel complete recombinant Alu sequence was formed in the mutation breakpoint. In contrast, sequence identity around breakpoints of rearrangements exon3_12del and exon9_15del was not

Table 1 Primers for LDLR breakpoint analysis

\begin{tabular}{|c|c|c|c|}
\hline $\begin{array}{l}\text { Mutation at cDNA } \\
\text { level }\end{array}$ & $\begin{array}{l}\text { Primers for long-range PCR } \\
\left(5^{\prime} \diamond 3^{\prime} \text { direction) }\right.\end{array}$ & $\begin{array}{l}\text { Size* } \\
(k b)\end{array}$ & $\begin{array}{l}\text { Primers for precise breakpoint } \\
\text { determination } \\
\left(5^{\prime}-3^{\prime} \text { direction) }\right.\end{array}$ \\
\hline promoter_ex2del & $\begin{array}{l}\text { F: TGTCGCAAATGGCATAAGGAA } \\
\text { R: CGGATITGCAGGTGACAGACA }\end{array}$ & 2.0 & $\begin{array}{l}\text { F: AAGGCTGCAGTGAAGTATGATGG } \\
\text { R: GAGACGGAGTCTCACTCTGTCG }\end{array}$ \\
\hline exon2_6dup & $\begin{array}{l}\text { F: AGTTCAAGTGTCACAGCGGC } \\
\text { R: GTCTTGGCACTGGAACTCGT }\end{array}$ & 8.0 & $\begin{array}{l}\text { F: AGTTCAAGTGTCACAGCGGC } \\
\text { R: CAAGGTTGGCGTITTCATATT }\end{array}$ \\
\hline exon3_12del & $\begin{array}{l}\text { F: CCAGAAGATTCCAGAAATTTCCAG } \\
\text { R: CCTTCTCCTITCCTCTCTCTCA }\end{array}$ & 3.5 & $\begin{array}{l}\text { F: TGGCTCACTGCAAGCTCCG } \\
\text { R: AGGCTGGAGTCCAGTGGTACC }\end{array}$ \\
\hline exon4_8dup & $\begin{array}{l}\text { F: CAAGTGCCAGTGTGAGGAAGG } \\
\text { R: CCCTTGGAACACGTAAAGACCC }\end{array}$ & 2.5 & $\begin{array}{l}\text { F: CACGTGACTTCAAGGGGTTAAAG } \\
\text { R: TTCTCTAAAATGCTTGGGACCA }\end{array}$ \\
\hline exon5_10del & $\begin{array}{l}\text { F: CACCTGCATCCCCCAGCTGTGGGC R: } \\
\text { TGGCTGGGACGGCTGTCCTGCGAAC }\end{array}$ & 3.0 & $\begin{array}{l}\text { F: TTTGTACAGACACAGGCTGGTC } \\
\text { R: CAGATGTCACCTGACAGGTACAG }\end{array}$ \\
\hline exon9_14del & $\begin{array}{l}\text { F: GGAGTGACTTCAAGGGGTTAAAG } \\
\text { R: AGGTGGCTCAGGCTGGGC }\end{array}$ & 0.5 & $\begin{array}{l}\text { F: GGAGTGACTTCAAGGGGTTAAAG } \\
\text { R: AGGTGGCTCAGGCTGGGC }\end{array}$ \\
\hline exon9_15del & $\begin{array}{l}\text { F: CACGTGATCGTCCCGCCTA } \\
\text { R: AAATTCTTGTCAACCTACTTGTGC }\end{array}$ & 0.8 & $\begin{array}{l}\text { F: AAATTCTTGTCAACCTACTTGTGC } \\
\text { R: CACGTGATCGTCCCGCCTA }\end{array}$ \\
\hline exon16_18dup & $\begin{array}{l}\text { F: CGTGAACATCTGCCTGGAGTC } \\
\text { R: TCTTCTCATITCCTCTGCCAGC }\end{array}$ & 3.0 & $\begin{array}{l}\text { F: TCGTGTGTGTTGGGATGGGA } \\
\text { R: ACCCCAGCCCCCAAACTAAA }\end{array}$ \\
\hline
\end{tabular}

$\mathrm{F}$ - forward primer; $\mathrm{R}$ - reverse primer; ${ }^{*}$ size of PCR fragment of mutated allele. The genomic sequence of the $L D L R$ gene was obtained from http://www.ucl.ac. uk/ldlr/LOVDv.1.1.0/refseq/LDLR_codingDNA.html. 
Table 2 Genomic characteristics of deletion and duplication breakpoints in the LDLR gene in Czech FH patients

\begin{tabular}{|c|c|c|c|c|c|c|}
\hline $\begin{array}{c}\text { Mutation at cDNA } \\
\text { level }\end{array}$ & $\begin{array}{c}\text { Mutation at DNA } \\
\text { level }\end{array}$ & $\begin{array}{c}\text { Deletion/ } \\
\text { duplication size }\end{array}$ & $\begin{array}{c}\text { Recombination } \\
\text { mechanism }\end{array}$ & $\begin{array}{l}\text { Repetitive element } 5^{\prime} / \\
\text { class/family }\end{array}$ & $\begin{array}{c}\text { Repetitive element } 3^{\prime} / \\
\text { class/family }\end{array}$ & $\begin{array}{c}\text { No. of } \\
\text { probands }\end{array}$ \\
\hline promoter_2exondel & $\begin{aligned} \text { C. } & -1823 \_190 \\
& +566 \mathrm{del}\end{aligned}$ & $13186 \mathrm{bp}$ & NAHR & AluY/SINE/Alu & AluY/SINE/Alu & 1 \\
\hline exon2_6dup & $\begin{array}{l}\text { c. } 67+3968 \_940 \\
+296 \text { dup }\end{array}$ & 14228bp & NAHR & AluSx1/SINE/Alu & AluSx3/SINE/Alu & 9 \\
\hline exon3_12del & $\begin{array}{c}\text { c. } 190+984 \_1846- \\
1160 \text { del }\end{array}$ & 17604bp & NAHR & FLAM_A/SINE/Alu & AluY/SINE/Alu & 1 \\
\hline exon4_8dup & $\begin{array}{l}\text { c.314-446_1187- } \\
\text { 386dup }\end{array}$ & $8119 \mathrm{bp}$ & NHEJ & AluSx1/SINE/Alu & MER83/LTR/ERV1 & 1 \\
\hline exon5_10del & $\begin{array}{l}\text { c. } 695-67 \_1586 \\
+371 \text { del }\end{array}$ & 7636bp & NHEJ & AluJo/SINE/Alu & AluSx1/SINE/Alu & 4 \\
\hline exon9_14del & $\begin{array}{c}\text { c.1186+700_2141- } \\
545 \mathrm{del}\end{array}$ & $10291 b p$ & NAHR & AluYa5/SINE/Alu & AluY/SINE/Alu & 10 \\
\hline exon9_15del) & $\begin{array}{c}\text { c.1187- } \\
\text { 169_2312-790del }\end{array}$ & $14110 \mathrm{bp}$ & NAHR & AluJb/SINE/Alu & AluSx1/SINE/Alu & 8 \\
\hline exon16_18dup) & $\begin{array}{c}\text { c.2311 } \\
+1941{ }^{*} 1216 \text { dup }\end{array}$ & 7248bp & NAHR & AluYb8/SINE/Alu & AluSq2/SINE/Alu & 3 \\
\hline
\end{tabular}

Newly described rearrangements are in bold letters; NAHR: nonallelic homologous recombination; NHEJ: nonhomologous end joining.

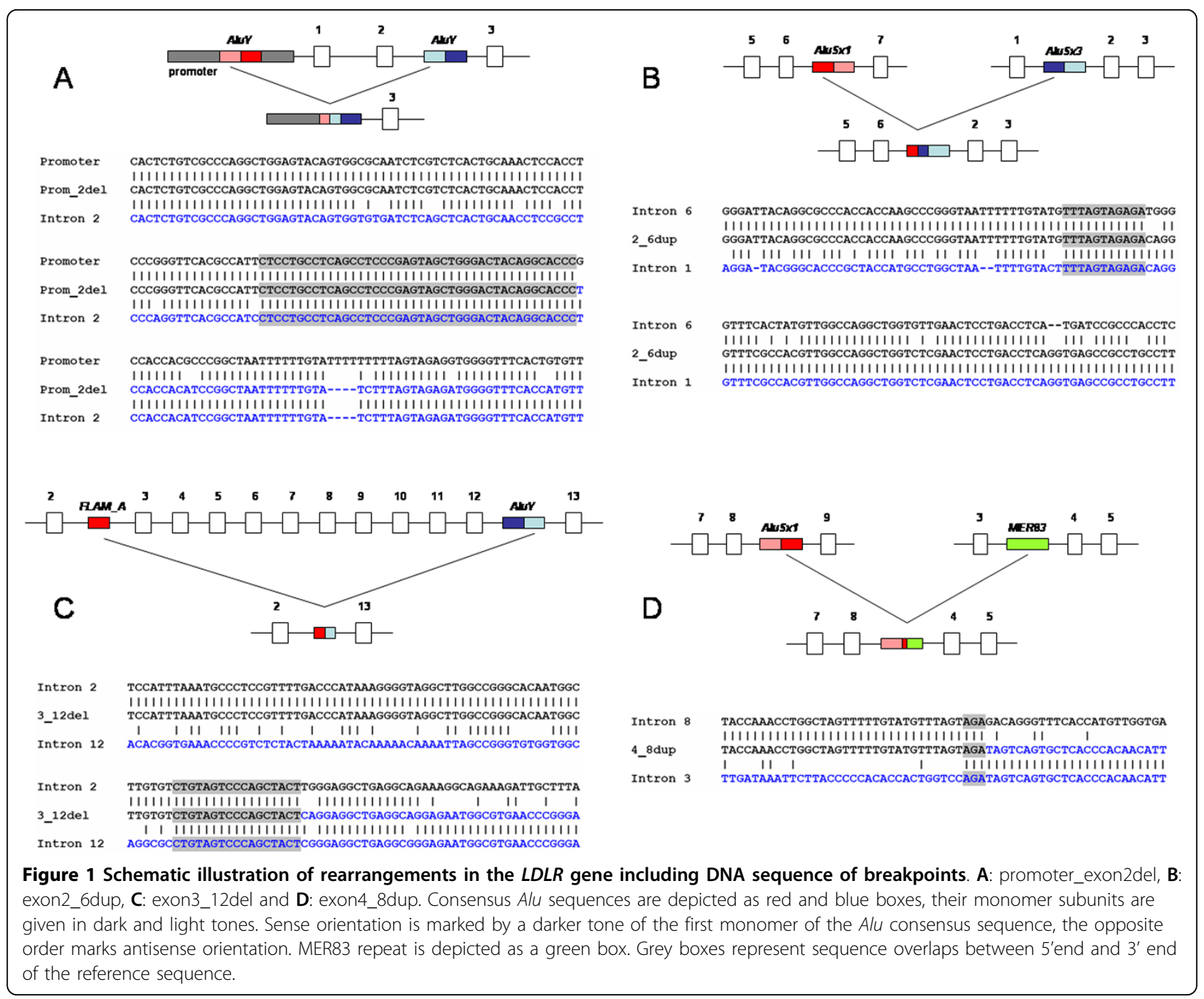




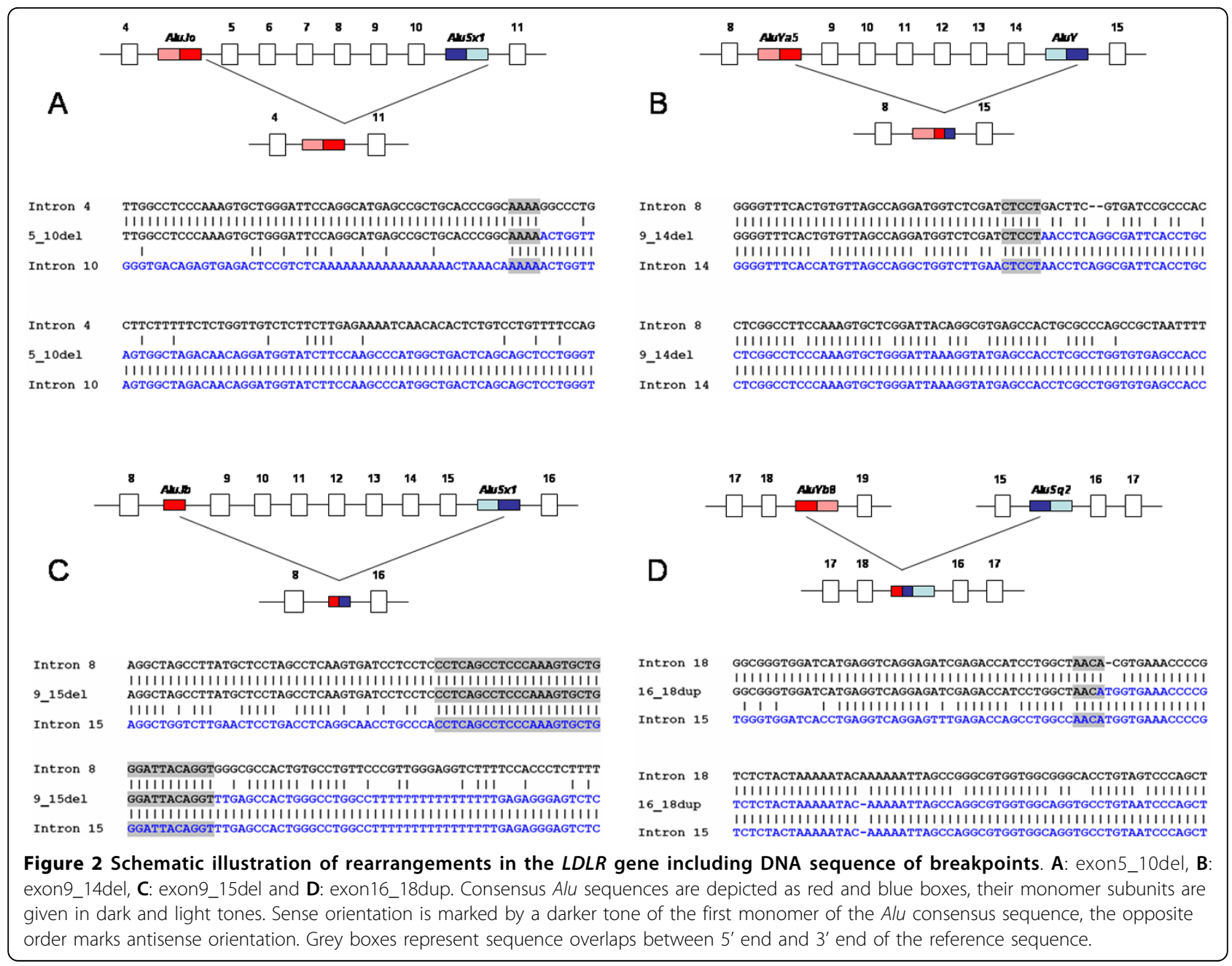

so extensive like in previous cases. These mutations were caused by recombination between an Alu repeat in monomer status and a consensus $A l u$ repeat (dimer status). The recombination between FLAM_A (free left Alu monomer, size: $133 \mathrm{bp}$ ) and AluY (size: $315 \mathrm{bp}$ ) was detected in exon3_12del. The recombination between AluJb (size: $137 \mathrm{bp}$ ) and AluSx1 (size: $311 \mathrm{bp}$ ) was identified in exon9_15del. The deletion breakpoints of both consensus $A l u$ repeats were localised in right monomer and so novel complete monomer recombinant $A l u$ sequence was formed in the mutation breakpoint. Promoter_exon2del, exon2_6dup, exon9_14del and exon9_15del were formed between Alu repeats in the antisense orientation, exon3_12del and exon16_18dup between $\mathrm{Alu}$ repeats in the sense orientation.

NHEJ was detected in two DNA rearrangements (exon5_10del and exon4_8dup). In exon5_10del, the breakpoint localized in intron 4 was present at the end of the AluJo repeat in antisense orientation, and the breakpoint localized in intron 10 was at the end of the AluSx 1 repeat in the sense orientation. In exon4_8dup, the breakpoint in intron 3 was localized in the MER83 repeat (ERV1 family repeat) and the breakpoint in intron 8 in the AluSx 1 sequence. There is no sequence homology between these repeats.

\section{Discussion}

The 117 large DNA rearrangements are listed on http:// www.ucl.ac.uk/ldlr/Current/index.php?select_db=LDLR [7]: 100 deletions and 17 duplications. In the view of 98 Alu repeats within the $L D L R$ gene [10], it is probable that DNA rearrangement breakpoints are located inside of Alu repetitive sequences. In the set of our FH patients, we detected 37 large DNA rearrangements in the $L D L R$ gene and performed the precise characterization of breakpoints in all types of deletions and duplications. Results define most of breakpoints inside of $A l u$ repeats (except one localised in ERV1 repeat) and NAHR and NHEJ as responsible for these rearrangements. Our results thus demonstrate that $A l u$ mediated recombination leads to massive disturbances in the structural and functional integrity of the $L D L R$ gene region. 
Promoter_exon2del is 13186 bp long and was detected in one Czech FH proband. Approximately $20 \mathrm{~kb}$ and 18 $\mathrm{kb}$ deletions of promoter, exon 1 and 2 were described previously [32,33]. Exon3_12del detected in one Czech FH proband was not described previously but deletions involving exon 3 were identified (exon3del [34], exon3_5del [35], exon3_6del [34], exon3_8del [36], and exon3_10del [37]). Exon5_10del was found in 4 Czech FH probands and was not described previously. Deletions encompassing exon 5 (exon5del and exon5_6del) were detected in studies [34,38], respectively. Exon9_14del was detected in 10 Czech FH probands. Niessen et al. found exon9_14del in Danish FH patients and performed also analysis of breakpoints. The correct size of the deletion described by Niessen was 9713 bp and both deletion breakpoints were localised in repetitive elements AluSq [39]. Exon9_14del determined in our FH probands sized $10291 \mathrm{bp}$ and breakpoints were localised in repetitive elements AluYa5 and AluY. Exon9_10del and exon9_12del were also detected in literature [40]. Exon9_15del was present in 8 Czech FH probands and was not described previously.

All duplications detected in our FH patients were new, not described so far. Exon2_6dup was detected in 9 Czech FH probands, exon4_8dup was found in one Czech FH proband, and exon16_18dup was determined in $3 \mathrm{Czech} \mathrm{FH}$ probands. The duplications exon2_8dup, exon4_5dup, and exon16_17dup were described [41-43].

It is interesting that exon2_6dup and exon9_15del were not described in literature and on http://www.ucl. ac.uk/ldlr/Current/index.php?select_db=LDLR, but in Czech $\mathrm{FH}$ patients these are relatively frequent (9 and 8 probands, respectively).

In the above mentioned work, Nissen et al. [39] described 5 genomic deletions in the $L D L R$ gene and defined the breakpoints of each deletion. The five deletions were flanked by $A l u$ elements, supporting a mutation mechanism involving unequal homologous recombination between highly similar Alu elements. The deletion exon13_15del described by Nissen et al. was flanked by two AluSg elements and 15 bp had been inserted at the site of the deleted DNA. This short insertion did not show similarity to any interspersed repeats or any other DNA sequence in the LDLR gene. However, the sequence shows partial homology to several sites in human genome. It is possible to speculate, that in this particular case, the final sequence arrangement has been generated by a more complex mechanism of double strand break repair, involving several recombination steps (e.g., resection and invasion of one DNA strand to a site of a partial homology and its elongation, which was not followed by the single-strand annealing step of homologous recombination, but instead by synthesis-dependent NHEJ). Alternatively, this kind of deletion could have been produced by NHEJ alone, without previous steps of homologous recombination). However, this cannot be clearly distinguished from the final sequence.

In this respect it should be mentioned that deletion and duplication spectra as the outcomes of recombination events in a given genomic locus are influenced not only by the DNA sequence context in the region itself (e.g., abundance and orientation of repeats and their variability) [44,45], but also by epigenetic factors. It corresponds to the fact that it is chromatin template, not a naked DNA, which is a subject of recombination. In the particular case of Alu repeats, the role of heterochromatic marks such as DNA methylation, or histone H3K9 methylation in suppression of recombination by these elements has been suggested in recent studies [46-48].

\section{Conclusions}

Eight different types of large genomic rearrangements were detected in the $L D L R$ gene, from them 6 types were novel, not described so far. Sequence analysis of deletion and duplication breakpoints indicates that both intrachromatid non-allelic homologous recombination (NAHR), and non-homologous end joining (NHEJ) are involved in $L D L R$ genomic rearrangements. While NAHR has been described in relation to the $L D L R$ gene, this study as the first describes NHEJ in $L D L R$ genomic rearrangements.

\section{Acknowledgements}

We would like to thank to physicians from the national (M. Vrablík, prof. R. Češka) and regional centres of the Czech MedPed project (V. Bláha, M. Budíková, J. Buryška, R. Cífková, L. Dlouhý, L. Dostálová-Kopečná, H. Halámková, J. Hyánek, J. Hyjánek, Z. Krejsová, J. Macháček, Š. Malá, J. Malý, V. Miláček, J. Mraček, H. Podzimková, D. Povalačová, H. Rosolová, F. Stožický, E. Šipková, L. Tooukálková, Z. Urbanová, H. Vaverková, S. Zemek, A. Žák) and other physicians participating in this project for providing us with their patients' blood samples and clinical and laboratory data, and to J. Porupková and M. Plotěná for technical assistance. This work was funded by the Czech Ministry of Education (projects 2B08060, LC06023, and MSM0021622415).

\section{Author details}

${ }^{1}$ University Hospital Brno, Centre of Molecular Biology and Gene Therapy, Černopolní 9, CZ-62500 Brno, Czech Republic. ${ }^{2}$ Centre for Cardiovascular Surgery and Transplantation, Pekařská 53, CZ-656 91 Brno, Czech Republic. ${ }^{3}$ St. Anne's University Hospital Brno, Department of Clinical Biochemistry, Pekařská 53, CZ-656 91 Brno, Czech Republic. ${ }^{4}$ Masaryk University, Faculty of Science, Institute of Experimental Biology, Department of Functional Genomics and Proteomics, Kamenice 5, CZ-62500 Brno, Czech Republic

\section{Authors' contributions}

RG performed detection of deletions/duplications in the $L D L R$ gene using MLPA and detailed characterization of breakpoints, LT performed detection of deletions/duplications in the LDLR gene using MLPA and administrated database of patients, PZ and OL performed molecular analysis of the $L D L R$ gene using PCR-RFLP, DNA sequencing and denaturing high performance liquid chromatography. TF and VS performed clinical examination, selection of patients with suspicion for familial hypercholesterolemia, and blood collections for DNA isolation. LF designed and coordinated the study and has been involved in evaluation of results and manuscript preparation. JF 
has been involved in evaluation of results and manuscript preparation. All authors read and approved the final manuscript.

\section{Competing interests}

The authors declare that they have no competing interests.

Received: 12 January 2010 Accepted: 27 July 2010

Published: 27 July 2010

\section{References}

1. Goldstein JL, Hobbs HH, Brown MS: Familial hypercholesterolemia. The Metabolic and Molecular Bases of Inherited Disease New York: McGraw-Hill Medical Publishing DivisionScriver CR, Baudet AL, Sly WS, Valle D 2001, 2863-2910.

2. Neil A, Cooper J, Betteridge J, Capps N, McDowell I, Durrington P, Seed M, Humphries SE: Reductions in all-cause, cancer, and coronary mortality in statin-treated patients with heterozygous familial hypercholesterolaemia: a prospective registry study. Eur Heart J 2008, 29(21):2625-2633.

3. Versmissen J, Oosterveer DM, Yazdanpanah M, Defesche JC, Basart DC, Liem AH, Heeringa J, Witteman JC, Lansberg PJ, Kastelein JJ, et al: Efficacy of statins in familial hypercholesterolaemia: a long term cohort study. BMJ 2008, 337:a2423.

4. Civeira F: Guidelines for the diagnosis and management of heterozygous familial hypercholesterolemia. Atherosclerosis 2004, 173(1):55-68.

5. Marks D, Thorogood M, Neil HA, Humphries SE: A review on the diagnosis, natural history, and treatment of familial hypercholesterolaemia. Atherosclerosis 2003, 168(1):1-14.

6. Hobbs HH, Russell DW, Brown MS, Goldstein JL: The LDL receptor locus in familial hypercholesterolemia: mutational analysis of a membrane protein. Annu Rev Genet 1990, 24:133-170.

7. Leigh SE, Foster AH, Whittall RA, Hubbart CS, Humphries SE: Update and analysis of the University College London low density lipoprotein receptor familial hypercholesterolemia database. Ann Hum Genet 2008, 72(Pt 4):485-498.

8. Hobbs HH, Lehrman MA, Yamamoto T, Russell DW: Polymorphism and evolution of Alu sequences in the human low density lipoprotein receptor gene. Proc Natl Acad Sci USA 1985, 82(22):7651-7655.

9. Hobbs HH, Brown MS, Goldstein JL: Molecular genetics of the LDL receptor gene in familial hypercholesterolemia. Hum Mutat 1992, 1(6):445-466.

10. Amsellem $S$, Briffaut $D$, Carrie $A$, Rabes JP, Girardet JP, Fredenrich $A$, Moulin P, Krempf M, Reznik Y, Vialettes B, et al: Intronic mutations outside of Alu-repeat-rich domains of the LDL receptor gene are a cause of familial hypercholesterolemia. Hum Genet 2002, 111(6):501-510.

11. Deininger $P L$, Batzer MA: Alu repeats and human disease. Mol Genet Metab 1999, 67(3):183-193.

12. Fuhrman SA, Deininger PL, LaPorte P, Friedmann T, Geiduschek EP: Analysis of transcription of the human Alu family ubiquitous repeating element by eukaryotic RNA polymerase III. Nucleic Acids Res 1981, 9(23):6439-6456.

13. Willis IM: RNA polymerase III. Genes, factors and transcriptional specificity. Eur J Biochem 1993, 212(1):1-11.

14. Weiner AM, Deininger PL, Efstratiadis A: Nonviral retroposons: genes, pseudogenes, and transposable elements generated by the reverse flow of genetic information. Annu Rev Biochem 1986, 55:631-661.

15. Mighell AJ, Markham AF, Robinson PA: Alu sequences. FEBS Lett 1997 417(1):1-5.

16. Shen MR, Batzer MA, Deininger PL: Evolution of the master Alu gene(s). J Mol Evol 1991, 33(4):311-320.

17. Batzer MA, Deininger PL, Hellmann-Blumberg U, Jurka J, Labuda D, Rubin CM, Schmid CW, Zietkiewicz E, Zuckerkandl E: Standardized nomenclature for Alu repeats. J Mol Evol 1996, 42(1):3-6.

18. Roy AM, Carroll ML, Kass DH, Nguyen SV, Salem AH, Batzer MA Deininger PL: Recently integrated human Alu repeats: finding needles in the haystack. Genetica 1999, 107(1-3):149-161.

19. Roy AM, Carroll ML, Nguyen SV, Salem AH, Oldridge M, Wilkie AO, Batzer MA, Deininger PL: Potential gene conversion and source genes for recently integrated Alu elements. Genome Res 2000, 10(10):1485-1495.

20. Slagel V, Flemington E, Traina-Dorge V, Bradshaw H, Deininger P: Clustering and subfamily relationships of the Alu family in the human genome. $\mathrm{Mol}$ Biol Evol 1987, 4(1):19-29.
21. Shaw CJ, Lupski JR: Implications of human genome architecture for rearrangement-based disorders: the genomic basis of disease. Hum $\mathrm{Mol}$ Genet 2004, 13(Spec No 1):R57-64.

22. de Smith AJ, Walters RG, Coin LJ, Steinfeld I, Yakhini Z, Sladek R, Froguel P, Blakemore Al: Small deletion variants have stable breakpoints commonly associated with alu elements. PLoS One 2008, 3(8):e3104.

23. Linardopoulou EV, Williams EM, Fan Y, Friedman C, Young JM, Trask BJ: Human subtelomeres are hot spots of interchromosomal recombination and segmental duplication. Nature 2005, 437(7055):94-100.

24. Korbel JO, Urban AE, Affourtit JP, Godwin B, Grubert F, Simons JF, Kim PM Palejev D, Carriero NJ, Du L, et al: Paired-end mapping reveals extensive structural variation in the human genome. Science 2007, 318(5849):420-426

25. Perry GH, Ben-Dor A, Tsalenko A, Sampas N, Rodriguez-Revenga L, Tran CW Scheffer A, Steinfeld I, Tsang P, Yamada NA, et al: The fine-scale and complex architecture of human copy-number variation. Am J Hum Genet 2008, 82(3):685-695.

26. Chan $\mathrm{CY}$, Kiechle M, Manivasakam $\mathrm{P}$, Schiestl $\mathrm{RH}$ : lonizing radiation and restriction enzymes induce microhomology-mediated illegitimate recombination in Saccharomyces cerevisiae. Nucleic Acids Res 2007, 35(15):5051-5059.

27. Lee K, Lee SE: Saccharomyces cerevisiae Sae2- and Tel1-dependent single-strand DNA formation at DNA break promotes microhomologymediated end joining. Genetics 2007, 176(4):2003-2014.

28. Innerarity TL, Weisgraber KH, Arnold KS, Mahley RW, Krauss RM, Vega GL, Grundy SM: Familial defective apolipoprotein B-100: low density lipoproteins with abnormal receptor binding. Proc Natl Acad Sci USA 1987, 84(19):6919-6923.

29. Soria LF, Ludwig EH, Clarke HR, Vega GL, Grundy SM, McCarthy BJ: Association between a specific apolipoprotein $B$ mutation and familial defective apolipoprotein B-100. Proc Natl Acad Sci USA 1989, 86(2):587-591.

30. Civeira F, Ros E, Jarauta E, Plana N, Zambon D, Puzo J, Martinez de Esteban JP, Ferrando J, Zabala S, Almagro F, et al: Comparison of genetic versus clinical diagnosis in familial hypercholesterolemia. Am J Cardiol 2008, 102(9):1187-1193, 1193 e1181.

31. Taylor A, Wang D, Patel K, Whittall R, Wood G, Farrer M, Neely RD, Fairgrieve S, Nair D, Barbir M, et al: Mutation detection rate and spectrum in familial hypercholesterolaemia patients in the UK pilot cascade project. Clin Genet 2009, 77(6):572-80.

32. Garuti R, Lelli N, Barozzini M, Tiozzo R, Ghisellini M, Simone ML, Li Volti S, Garozzo R, Mollica F, Vergoni W, et al: Two novel partial deletions of LDLreceptor gene in Italian patients with familial hypercholesterolemia (FH Siracusa and FH Reggio Emilia). Atherosclerosis 1996, 121(1):105-117.

33. Chaves FJ, Real JT, Garcia-Garcia AB, Puig O, Ordovas JM, Ascaso JF, Carmena R, Armengod ME: Large rearrangements of the $L D L$ receptor gene and lipid profile in a FH Spanish population. Eur J Clin Invest 2001, 31(4):309-317

34. Fouchier SW, Kastelein JJ, Defesche JC: Update of the molecular basis of familial hypercholesterolemia in The Netherlands. Hum Mutat 2005, 26(6):550-556.

35. Chang JH, Pan JP, Tai DY, Huang AC, Li PH, Ho HL, Hsieh HL, Chou SC, Lin WL, Lo $E$, et al: Identification and characterization of $L D L$ receptor gene mutations in hyperlipidemic Chinese. J Lipid Res 2003, 44(10):1850-1858.

36. Fouchier SW, Defesche JC, Umans-Eckenhausen MW, Kastelein JP: The molecular basis of familial hypercholesterolemia in The Netherlands. Hum Genet 2001, 109(6):602-615.

37. Bertolini S, Garuti R, Lelli W, Rolleri M, Tiozzo RM, Ghisellini M, Simone ML, Masturzo P, Elicio NC, Stefanutti C, et al: Four novel partial deletions of LDL-receptor gene in Italian patients with familial hypercholesterolemia. Arterioscler Thromb Vasc Biol 1995, 15(1):81-88.

38. Hobbs HH, Brown MS, Goldstein JL, Russell DW: Deletion of exon encoding cysteine-rich repeat of low density lipoprotein receptor alters its binding specificity in a subject with familial hypercholesterolemia. $J$ Biol Chem 1986, 261(28):13114-13120.

39. Nissen PH, Damgaard D, Stenderup A, Nielsen GG, Larsen ML, Faergeman O: Genomic characterization of five deletions in the LDL receptor gene in Danish Familial Hypercholesterolemic subjects. BMC Med Genet 2006, 7:55. 
40. Holla OL, Teie C, Berge KE, Leren TP: Identification of deletions and duplications in the low density lipoprotein receptor gene by MLPA. Clin Chim Acta 2005, 356(1-2):164-171.

41. Lehrman MA, Goldstein JL, Russell DW, Brown MS: Duplication of seven exons in LDL receptor gene caused by Alu-Alu recombination in a subject with familial hypercholesterolemia. Cell 1987, 48(5):827-835.

42. Koeijvoets KC, Rodenburg J, Hutten BA, Wiegman A, Kastelein JJ, Sijbrands EJ: Low-density lipoprotein receptor genotype and response to pravastatin in children with familial hypercholesterolemia: substudy of an intima-media thickness trial. Circulation 2005, 112(20):3168-3173.

43. Lelli N, Ghisellini M, Gualdi R, Tiozzo R, Calandra S, Gaddi A, Ciarrocchi A, Arca M, Fazio S, Coviello DA, et al: Characterization of three mutations of the low density lipoprotein receptor gene in Italian patients with familial hypercholesterolemia. Arterioscler Thromb 1991, 11(2):234-243.

44. Gebow D, Miselis N, Liber HL: Homologous and nonhomologous recombination resulting in deletion: effects of p53 status, microhomology, and repetitive DNA length and orientation. Mol Cell Biol 2000, 20(11):4028-4035.

45. Costantini M, Bernardi G: Mapping insertions, deletions and SNPs on Venter's chromosomes. PLoS One 2009, 4(6):e5972.

46. Kondo Y, Issa JP: Enrichment for histone H3 lysine 9 methylation at Alu repeats in human cells. J Biol Chem 2003, 278(30):27658-27662.

47. Salih F, Salih B, Kogan S, Trifonov EN: Epigenetic nucleosomes: Alu sequences and CG as nucleosome positioning element. J Biomol Struct Dyn 2008, 26(1):9-16.

48. Schulz WA, Steinhoff C, Florl AR: Methylation of endogenous human retroelements in health and disease. Curr Top Microbiol Immunol 2006 310:211-250.

\section{Pre-publication history}

The pre-publication history for this paper can be accessed here:

http://www.biomedcentral.com/1471-2350/11/115/prepub

doi:10.1186/1471-2350-11-115

Cite this article as: Goldmann et al:: Genomic characterization of large rearrangements of the $L D L R$ gene in Czech patients with familial hypercholesterolemia. BMC Medical Genetics 2010 11:115.

\section{Submit your next manuscript to BioMed Central} and take full advantage of:

- Convenient online submission

- Thorough peer review

- No space constraints or color figure charges

- Immediate publication on acceptance

- Inclusion in PubMed, CAS, Scopus and Google Scholar

- Research which is freely available for redistribution

Submit your manuscript at www.biomedcentral.com/submit
Biomed Central 